\title{
Faktor-Faktor Yang Berhubungan Dengan Perilaku Seksual Pranikah Remaja
}

\author{
${ }^{1}$ Elvira*,${ }^{2}$ Sutanto Priyo Hastono, ${ }^{3}$ Siti Maisytah \\ Universitas Respati Indonesia \\ *email: vier_lo3s@yahoo.co.id
}

\begin{abstract}
Abstrak
Kata Kunci :

Usia remaja merupakan usia yang sangat aktif termasuk dalam dorongan dan perilaku seksualnya. Pada masa remaja, rasa ingin tahu mengenai seksualitas sangat penting terutama dalam pembentukan hubungan dengan lawan jenisnya.Besarnya keingintahuan remaja mengenai hal-hal yang berhubungan dengan Perilaku

Merokok, seksualitas menyebabkan remaja selalu berusaha mencari informasi lebih banyak mengenai seksualitas.

Pengetahuan,

Sikap,

Kegiatan UKS Mengetahui faktor-faktor yang berhubungan dengan perilaku seksual pranikah remaja di SMA N 1 Pemali, Bangka Tahun 2016. Jenis penelitian ini adalah kuntitatif dengan jenis non ekperimental dengan rancangan cross sectional. Populasi penelitian ini seluruh siswa/siswi kelas X SMA N 1 Pemali, Bangka dengan estimasi jumlah populasi sebanyak 292 responden. Teknik sampling yang digunakan adalah total sampling dengan jumlah sampel 279 dan 16 sampel dikeluarkan karena ketidakhadiran responden saat pelaksanaan penelitian. Alat pengumpulan data menggunakan angket dalam bentuk kuesioner.Waktu penelitian dilaksanakan pada tanggal 5 Desember 2016. Analisis data peneltian menggunakan analisis univariat, bivariat dan multivariat. Ada hubungan yang signifikan antara pengetahuan $(p$-value $=0.026)$, jenis kelamin $(p$-value $=0.005)$, pola asuh orang tua $(p$-value $=0.005)$, pendidikan orang tua (pendidikan ayah ( $p$-value $=0.008)$, pendidikan ibu $(p$-value $=0.037)$, ketaatan beribadah $(p$-value $=0.001)$, paparan media

\section{Key Words:}

Premarital

Sexual

Behavior

Factor,

Adolescent pornografi $(p$-value $=0.005)$, pacaran $(p$-value $=0.005)$ dan pengaruh teman sebaya $(p$-value $=0.005)$ dengan perilaku seksual pranikah remaja di SMA N 1 Pemali Bangka tahun 2016. Tidak ada hubungan yang signifikan antara sikap ( $p$-value $=0.095)$, tempat tinggal $(p$-value $=0.296)$, dan pendapatan orang tua $(p$-value $=0.303)$ dengan dengan perilaku seksual pranikah remaja di SMA N 1 Pemali Bangka tahun 2016. Faktor yang paling dominan dalam penelitian ini adalah variabel pacaran dengan $\mathrm{OR}=20.595$. Perilaku seksual pranikah berhubungan dengan pengetahuan, jenis kelamin, pola asuh orang tua, pendidikan orang tua, ketaatan beribadah, paparan media pornografi, pacaran dan teman sebaya di SMA N 1 Pemali, Bangka Tahun 2016.
\end{abstract}

Kata Kunci $\quad$ : Faktor Perilaku Seksual Pranikah, Remaja

\section{Abstract}

Info Artikel: Tanggal dikirim: 10 April 2019 Tanggal direvisi: 22 Mei 2019

Tanggal diterima:

27 Juni 2019

DOI Artikel: 10.33862/citrad elima.v3i1.32 Halaman: 15 24
The age of youth is very active age included in the impulse and sexual behavior. In adolescence, curiosity about sexuality is very important, especially in the establishment of relationships with the opposite sex. The amount of adolescent curiosity on matters relating to sexuality causes teens are always trying to find more information about sexuality. The purpose of a study: To identify factors associated with adolescent premarital sexual behavior in SMA N 1Pemali, Bangka 2016.Methods: The research is a kind of nonexperimental quantitative with cross sectional design. This population is all the student / student of class X SMA N 1 Pemali, Bangka with an estimated total population of 292 respondents. The sampling technique used is total sampling with a sample of 279 and 16 samples were excluded because of the absence of the respondent when conducting research. Data collection tool uses a questionnaire in the form of a questionnaire. The research was conducted on December 5, 2016. The data analysis of a study using univariate, bivariate and multivariate. Analyzes Results: There was a significant relationship between knowledge $(p$-value $=0.026)$, gender $(p$-value $=0.005)$, parents' parenting $(p$-value $=0.005)$, education of parents (father's education ( $\mathrm{p}$-value $=0.008)$, maternal education ( $\mathrm{p}$-value $=0.037)$, acts of worship ( $\mathrm{p}$ value $=0.001)$, exposure to pornographic media $(\mathrm{p}$-value $=0.005)$, dating $(\mathrm{p}$-value $=0.005)$ and the influence of peer group $(\mathrm{p}$-value $=0.005)$ with adolescent premarital sexual behavior in SMA N 1 Pemali Bangka 2016. there is no significant relationship between attitude $(p$-value $=0095)$, shelter $(p$-value $=$ 0.296), and the income of parents ( $\mathrm{p}$-value $=0303$ ) with the adolescent premarital sexual behavior in SMA N 1 Pemali Bangka 2016. the most dominant factor in this study is the variable courtship with OR $=20$ 595.Conclusion: Premarital sexual behavior is associated with knowledge, sex, parenting parents, parental education, acts of worship, media exposure to pornography, dating and peer SMA N 1 Pemali, Bangka 2016. 


\section{PENDAHULUAN}

Usia remaja merupakan usia yang sangat aktif termasuk dalam dorongan dan perilaku seksualnya. Pada masa remaja, rasa ingin tahu mengenai seksualitas sangat penting terutama dalam pembentukan hubungan dengan lawan jenisnya. Besarnya keingintahuan remaja mengenai hal-hal yang berhubungan dengan seksualitas menyebabkan remaja selalu berusaha mencari informasi lebih banyak mengenai seksualitas. ${ }^{15}$

Berdasarkan survey yang dilakukan oleh Badan Kependudukan dan Keluarga Berencana Naional (BKKBN), lebih dari seperlima dari laki-laki sudah meraba-raba saat berpacaran, lebih dari $45 \%$ remaja sudah pernah berciuman, $98 \%$ remaja SMP dan SMA sudah pernah menonton film porno, 95,5\% remaja SMP dan SMA pernah oral seks, 63,7\% remaja putri sudah tidak perawan, dan $22,2 \%$ remaja putri pernah aborsi. ${ }^{3}$

Adapun hasil penelitian yang dilakukan di tanggerang didapatkan hasil bahwa responden yang pernah berkontak fisik (pegangan tangan, memeluk atau mencium pipi) sebesar 58,3\%, mencium bibir $(22,4 \%)$ memegang payudara kekasih $(8,4 \%)$ memegang alat kelamin kekasih dengan tangan $(5,8 \%)$, mengelus kelamin kekasih hingga terangsang $(6,5 \%)$, pernah bersetubuh $(2,8 \%)$, melakukan bersetubuh 1 kali seminggu $(1,0 \%)$ dan melakukan aborsi $(0,45)$, pernah hamil setelah melakukan hubungan seksual $(0,6 \%){ }^{11}$

Bedasarkan studi pendahuluan yang dilakukan di SMA N 1 Pemali Bangka Pada tanggal 15 oktober 2016 dengan jumlah responden sebanyak 15 orang didapatkan hasil dari 15 siswa/siswi terdapat 14 responden yang pernah berpacaran dan 7 responden yang sedang berpacaran. Dari 14 responden yang pernah berpacaran ataupun yang sedang pacaran ada 3 responden yang berperilaku seksual tidak beresiko dan 11 responden yang berperilaku seksual yang beresiko.

\section{METODE}

Jenis penelitian ini adalah kuantitatif dengan jenis non eksperimental dengan rancangan cross sectional.Penelitian ini dilaksanakan di SMA N 1 Pemali Bangka pada tanggal 5 Desember 2016.Populasi adalah seluruh siswa kelas x SMA N 1 Pemali dengan jumlah sampel sebanyak 276 orang.

Teknik pengumpulan data dengan menggunakan angket.angket yaitu suatu alat pengumpulan data yang berupa serangkaian pertanyaan yang diajukan pada responden untuk menjawab. Pengumpulan data dengan angket dilakukan melalui cara mengedarkan daftar pertanyaan berupa formulir, diajukan secara tertulis kepada responden, untuk mendapat tanggapan, informasi, jawaban dan sebagainya

HASIL

Analisis Univariat

Tabel 1.

Distribusi Frekuensi siswa/siswi SMA N 1 Pemali, Bangka Tahun 2016

\begin{tabular}{|c|c|c|}
\hline Distribusi & Frekuensi & $\begin{array}{c}\text { Precent } \\
\text { ase }\end{array}$ \\
\hline \multicolumn{3}{|l|}{ Perilaku seksual } \\
\hline Beresiko & 111 & 40.2 \\
\hline Tidak Beresiko & 165 & 59.8 \\
\hline \multicolumn{3}{|l|}{ Pengetahuan } \\
\hline Rendah & 165 & 59.8 \\
\hline Tinggi & 165 & 59.8 \\
\hline \multicolumn{3}{|l|}{ Jenis Kelamin } \\
\hline Laki-laki & 105 & 38.0 \\
\hline Perempuan & 171 & 62.0 \\
\hline \multicolumn{3}{|l|}{ Sikap } \\
\hline Negatif & 10 & 3.6 \\
\hline Positif & 266 & 96.4 \\
\hline \multicolumn{3}{|l|}{ Pola Asuh Orang Tua } \\
\hline Tidak Demokratis & 66 & 23.9 \\
\hline Demokratis & 210 & 76.1 \\
\hline \multicolumn{3}{|l|}{ Pendidika Ayah } \\
\hline Rendah & 119 & 43.1 \\
\hline Tinggi & 157 & 56.9 \\
\hline \multicolumn{3}{|l|}{ Pendidikan Ibu } \\
\hline Rendah & 122 & 44.2 \\
\hline Tinggi & 154 & 55.8 \\
\hline \multicolumn{3}{|l|}{ Ketaatan Beragama } \\
\hline Tidak taat & 81 & 29.3 \\
\hline Taat & 195 & 70.7 \\
\hline Distribusi & Frekuensi & $\begin{array}{c}\text { Present } \\
\text { ase }\end{array}$ \\
\hline \multicolumn{3}{|l|}{ Tempat Tinggal } \\
\hline \multicolumn{3}{|l|}{ Tua } \\
\hline $\begin{array}{l}\text { Dengan } \\
\text { tua/keluarga }\end{array}$ & 262 & 94.9 \\
\hline Paparan & & \\
\hline \multicolumn{3}{|l|}{ Pornografi } \\
\hline Terpapar & 156 & 56.5 \\
\hline Tidak terpapar & 120 & 43.5 \\
\hline \multicolumn{3}{|l|}{ Pendapatan keluarga } \\
\hline$<\mathrm{UMK}$ & 140 & 50.7 \\
\hline$\geq \mathrm{UMK}$ & 136 & 49.3 \\
\hline Pacaran & & \\
\hline
\end{tabular}




\begin{tabular}{lcc}
\hline Sedang/Pernah & 187 & 67.8 \\
Tidak Pernah & 89 & 32.2 \\
Teman Sebaya & & \\
Negatif & 123 & 44.6 \\
Positif & 153 & 55.4 \\
\hline
\end{tabular}

Berdasarkan Tabel 5.2 diatas menunjukkan bahwa Remaja SMA N 1 Pemali, Bangka Tahun 2016 sebagian besar berperilaku seksual tidak beresiko sebanyak 165 responden (59.8\%), berpengetahuan rendah sebanyak 222 Responden $(80,4 \%)$, berjenis kelamin perempuan sebanyak 171 Responden (62.0\%), sikap remaja Positif sebanyak 266 Responden (96.4\%), Pola asuh orang tua Demokratis sebanyak 210 Responden (76.1\%), Pendidikan Ayah tinggi sebanyak 157 responden (56.9\%), Pendidikan Ibu tinggi sebanyak 154 responden $(55.8 \%)$, Taat beragama sebanyak 195 responden $(70.7 \%)$, Tinggal bersama orang tua dan keluarga sebanyak 262 orang (94.9\%), Terpapar Media Pornografi sebanyak 156 responden (56.5\%), Pendapatan keluarga < UMK sebanyak 140 responden $(50.7 \%)$, sedang dan atau pernah pacaran sebanyak 187 orang $(67.8 \%)$ dan teman sebaya berpengaruh positif sebanyak 153 responden $(55.4 \%)$.

\section{Analisis Bivariat}

Tabel 2.

Distribusi Frekuensi Variabel independen terhadap Perilaku Seksual Pranikah Remaja

\begin{tabular}{|c|c|c|c|c|c|}
\hline \multirow[t]{3}{*}{ Variabel } & \multicolumn{4}{|c|}{$\begin{array}{c}\text { Perilaku Seksual } \\
\text { Remaja }\end{array}$} & \multirow{3}{*}{$\begin{array}{c}P \\
\text { value } \\
/ \\
\text { OR }\end{array}$} \\
\hline & \multicolumn{2}{|c|}{ Beresiko } & \multicolumn{2}{|c|}{$\begin{array}{c}\text { Tidak } \\
\text { Beresiko }\end{array}$} & \\
\hline & $\mathbf{n}$ & $\%$ & $\mathbf{n}$ & $\%$ & \\
\hline Pengetahuan & & & & & \\
\hline Rendah & 97 & 43.7 & 125 & 56.3 & 0.026 \\
\hline Tinggi & 14 & 25.9 & 40 & 74.1 & / \\
\hline Jenis Kelamin & & & & & 2.217 \\
\hline Laki-laki & 60 & 57.1 & 45 & 42.9 & 0.005 \\
\hline Perempuan & 51 & 29.8 & 120 & 70.2 & $\begin{array}{l}\text { / } \\
3.137\end{array}$ \\
\hline Sikap & & & & & \\
\hline Negatif & 7 & 70.0 & 3 & 30.0 & 0.095 \\
\hline Positif & 104 & 39.1 & 162 & 60.9 & $\begin{array}{l}\text { / } \\
3.635\end{array}$ \\
\hline $\begin{array}{l}\text { Pola Asuh } \\
\text { Orang Tua }\end{array}$ & & & & & \\
\hline $\begin{array}{l}\text { Tidak } \\
\text { Demokratis }\end{array}$ & 48 & 72.7 & 16 & 27.3 & 0.005 \\
\hline Demokratis & 63 & 30.0 & 147 & 70.0 & 6.222 \\
\hline
\end{tabular}

\begin{tabular}{|c|c|c|c|c|c|}
\hline Pendidika & & & & & \\
\hline Ayah & & & & & \\
\hline Rendah & 59 & 49.6 & 60 & 50.4 & 0.008 \\
\hline Tinggi & 52 & 33.1 & 105 & 66.9 & \\
\hline & & $\begin{array}{r}\text { rilakı } \\
\text { ReI }\end{array}$ & $\begin{array}{l}\text { Sekst } \\
\text { aja }\end{array}$ & & $\begin{array}{c}p- \\
\text { value }\end{array}$ \\
\hline Variabel & Bet & siko & $\begin{array}{r}\text { Ti } \\
\text { Ber }\end{array}$ & $\begin{array}{l}\text { ak } \\
\text { siko }\end{array}$ & $\begin{array}{c}\text { I } \\
\text { OR }\end{array}$ \\
\hline & $\mathbf{n}$ & $\%$ & $\mathbf{n}$ & $\%$ & \\
\hline $\begin{array}{l}\text { Pendidikan } \\
\text { Ibu }\end{array}$ & & & & & \\
\hline Rendah & 58 & 47.5 & 64 & 52.5 & 0.037 \\
\hline Tinggi & 53 & 34.4 & 101 & 65.6 & I 1727 \\
\hline
\end{tabular}

Ketaatan

Beragama

Tidak taat

Taat

$\begin{array}{ccccl}48 & 59.3 & 33 & 40.7 & 0.005 \\ 63 & 32.3 & 132 & 67.7 & / \\ & & & & 3.048\end{array}$

Tempat

Tinggal

$\begin{array}{llllll}\text { Tidak Dengan } & 8 & 57.1 & 6 & 42.9 & 0.296\end{array}$

Orang Tua

$\begin{array}{llllll}\text { Dengan Orang } & 103 & 39.3 & 159 & 60.7 & 2.058\end{array}$

tua/keluarga

Paparan

Media

Pornografi

Terpapar

Tidak terpapar

$\begin{array}{ccccc}96 & 61.5 & 60 & 38.5 & 0.005 \\ 15 & 12.5 & 105 & 87.5 & /\end{array}$

11.20

0

Pendapatan

keluarga

$<\mathrm{UMK}$

$\geq \mathrm{UMK}$

$\begin{array}{lllll}61 & 43.6 & 79 & 56.4 & 0.303\end{array}$

$\begin{array}{lllll}50 & 36.8 & 86 & 63.2 \quad /\end{array}$

Pacaran

$\begin{array}{llllll}\text { Sedang/Pernah } & 108 & 57.8 & 79 & 42.2 & 0.005\end{array}$

$\begin{array}{llllll}\text { Tidak Pernah } & 3 & 3.4 & 86 & 96.6 \quad /\end{array}$

0

Teman Sebaya

$\begin{array}{lccccl}\text { Negatif } & 91 & 74.1 & 32 & 26.0 & 0.005 \\ \text { Positif } & 20 & 13.1 & 133 & 86.9 & /\end{array}$

Positif

18.91

Berdasarkan tabel 2 diatas variabel dengan p_value $<0.05$ adalah pengetahuan, jenis kelamin, pola asuh orang tua, pendidikan orang tua, ketaatan beragama, paparan media pornografi, pacaran, dan teman sebaya artinya variabel tersebut terdapat 
hubungan dengan perilaku seksual pranikah remaja di SMA N 1 Pemali Bangka Tahun 2016.

\section{Analisis Multivariat}

Pada analisis multivariat, langkah pertama adalah melakukan analisis bivariat terhadap semua variabel independen. Bila hasil bivariat pada test omnibus dengan blok menghasilkan nilai $\mathrm{p}<0.25$, maka variabel tersebut masuk dalam multivariat. tetapi apabila nilai $\mathrm{p}>0.2$, maka variabel tersebut dikeluarkan dalam multivariat.

Variabel yang masuk ke dalam model multivariat adalah Pengetahuan, jenis kelamin, sikap, pola asuh orang tua, pendidikan orang tua, ketaatan beribadah, tempat tinggal, pendapatan orang tua, paparan media pornografi, pacaran, dan teman sebaya.

Tabel 3

Hasil Analisis Multivariat Variabel Independen Dengan Perilaku Seksual Pranikah Remaja SMA N 1 Pemali, Bangka Tahun 2016

\begin{tabular}{clrc}
\hline No & $\begin{array}{l}\text { Variabel } \\
\text { Independen }\end{array}$ & $\begin{array}{c}\boldsymbol{P} \text { - } \\
\text { Value }\end{array}$ & OR \\
\hline 1 & Pengetahuan & .415 & 1.633 \\
2 & Jenis Kelamin & .145 & 1.799 \\
3 & Sikap & .133 & 11.865 \\
\hline \multirow{2}{*}{ No } & Variabel & $\begin{array}{c}\text { p- } \\
\text { Independen }\end{array}$ & OR \\
\hline \multirow{2}{*}{4} & Pola Asuh Orang & .008 & 3.804 \\
5 & Tua & & \\
6 & Pendidikan Ayah & .316 & 1.549 \\
7 & Pendidikan Ibu & .345 & 1.503 \\
8 & Ketaatan Beragama & .023 & 2.641 \\
9 & Tempat Tinggal & .142 & 4.336 \\
& Paparan Media & .000 & 4.757 \\
10 & Pornografi & & \\
11 & Pacaran & .000 & 20.783 \\
\hline
\end{tabular}

Berdasarkan hasil analisis regresi logistic, variabel yang berhubungan signifikan dengan perilaku seksual adalah Pacaran, Teman Sebaya, Paparan media Pornografi, Pola Asuh Orang Tua, dan Ketaatan Beragama. Dari lima variabel tersebut variabel yang dominan adalah variabel pacaran dengan $\mathrm{OR}=20.783$ (dibulatkan menjadi 21) yang artinya responden yang pacaran memiliki peluang 21 kali lebih besar berperilaku seksual pranikah yang beresiko dibandingkan dengan responden yang tidak pernah pacaran setelah di kontrol oleh variabel Sikap, Teman Sebaya, Paparan Media Pornografi, Tempat Tinggal, Pola Asuh Orang Tua, Ketaatan Beragama, Jenis Kelamin, Pengetahuan, Pendidikan Ayah, dan Pendidikan Ibu.

\section{PEMBAHASAN \\ Perilaku Seksual Pranikah}

Berdasarkan hasil penelitian diketahui responden yang berperilaku seksual pranikah remaja yang beresiko sebanyak 111 responden (40.2\%) sedangkan yang tidak beresiko sebanyak 165 Responden (59.8\%).

Dari hasil penelitian ini diketahui bahwa beberapa perilaku seksual pranikah remaja antara lain adalah pergi bekencan $(12.3 \%)$, bepegangan tangan $(72.1 \%)$, saling memeluk (43.8.\%), cium pipi (48.9\%), ciuman bibir (35.5\%), mencium leher $(11.6 \%)$, meraba payudara $(12.3 \%)$, meraba alat kelamin pasangan $(6.5 \%)$, saling menggesakkan alat kelamin $(4.3 \%)$, oral seks $(7.2 \%)$, onani atau masturbasi (10.1\%), dan hubungan intim (1.8\%).

Meskipun perilaku seksual yang dilakukan responden paling banyak adalah ciuman bibir 98 Responden (10.1\%), namun perilaku ciuman bibir tersebut masuk dalam kategori perilaku seksual beresiko yang dapat mendorong responden untuk melakukan perilaku seksual yang lebih beresiko lagi. Pada penelitian ini terdapat $5(1.8 \%)$ remaja yang sudah pernah melakukan hubungan intin (intercouse), berdasarkan penelitian remaja melakukan hal tersebut di dihotel dan di pantai.

Hasil penelitian diatas masih dikatagorikan tidak terlalu tinggi apabila dibandingkan dengan penelitian yang dilakukan oleh Reni Dwi Parihat (2015) didapatkan hasil bahwa responden yang pernah berkontak fisik (pegangan tangan, memeluk atau mencium pipi) sebesar 58,3\%, mencium bibir $(22,4 \%)$ memegang payudara kekasih $(8,4 \%)$ memegang alat kelamin kekasih dengan tangan $(5,8 \%)$, mengelus kelamin kekasih hingga terangsang $(6,5 \%)$, pernah bersetubuh $(2,8 \%)$, melakukan bersetubuh 1 kali seminggu $(1,0 \%)$ dan melakukan aborsi $(0,45)$, pernah hamil setelah melakukan hubungan seksual $(0,6 \%)$. Namun hal ini karena perbedaan karakteristik tempat penelitian yang dilakukan oleh Reni Dwi Parihat dengan lokasi penelitiannya di Tanggerang Selatan Jakarta.

\section{Hubungan Pengetahuan dengan Perilaku Seksual Pranikah Remaja}

Berdasarkan penelitian diketahui responden yang memiliki pengetahuan rendah sebanyak 222 responden (80.4\%) dengan perilaku seksual pranikah beresiko terdapat 97 responden $(43.7 \%)$, Sedangkan responden yang memiliki pengetahuan tinggi sebanyak 54 responden (19.6\%) dengan perilaku seksual pranikah beresiko sebanyak 14 responden $(25.9 \%)$.Hasil uji statistik menunjukkan p-value $=0.026<0.05$, maka dapat disimpulkan 
bahwa terdapat hubungan yang signifikan antara Pengetahuan dengan Perilaku Seksual Pranikah Remaja di SMA N 1 Pemali, Bangka Tahun 2016 dengan dinilai $\mathrm{OR}=2.217$ artinya remaja dengan pengetahuan rendah memiliki peluang 2 kali lebih besar untuk berperilaku seksual yang beresiko dibandingkan remaja denga pengetahuan tinggi.

Penelitian ini sejalan dengan penelitian yang dilakukan Di SMA N 2 Mukomuko Impuh Bengkulu Tahun 2015 bahwaada hubungan antara pengetahuan dengan Perilaku Seksual Pranikah Pada Remaja. ${ }^{8}$

Pengetahuan yang rendah dikarenakan kurangnya informasi yang didapat oleh remaja mengenai dampak dari perilaku seksual pranikah sehingga masih banyak remaja yang berperilaku seksual beresiko.semakin baik pengetahuan yang terbentuk, dan keterbatasan informasi dapat mempengaruhi pengetahuan menjadi kurang. ${ }^{7}$

Hubungan Jenis Kelamin dengan Perilaku Seksual Pranikah Remaja

Berdasarkan penelitian diketahui responden yang berjenis kelamin laki-laki sebanyak 105 responden $(38.0 \%)$ dengan perilaku seksual pranikah beresiko terdapat 60 responden $(57.1 \%)$, Sedangkan yang berjenis kelamin perempuan sebanyak 171 responden $(62.0 \%)$ dengan perilaku seksual beresiko sebanyak 51 responden $(18.5 \%)$.

Hasil uji statistik menunjukkan $p$-value $=0.005$ $<0.05$, maka Dapat disimpulkan bahwa terdapat hubungan yang signifikan antara Jenis Kelamin dengan Perilaku Seksual Pranikah Remaja di SMA N 1 Pemali, Bangka Tahun 2016 dengan dinilai OR $=3.137$ (dibulat menjadi 19) artinya remaja laki-laki memiliki peluang 3 kali lebih besar untuk berperilaku seksual yang beresiko dibandingkan dengan remaja berjenis kelamin perempuan.

Penelitian lain sejalan dengan penelitian di SMA Kota Tasikmalaya, Tahun 2013yang membuktikan bahwa ada hubungan yang signifikan antara Jenis Kelamin denga Perilaku Seksual Remaja. ${ }^{2}$

Remaja laki-laki memiliki motivasi lebih tinggi untuk melakukan hubungan seksual sebelum menikah karena memang remaja laki-laki lebih permisif. Dorongan untuk melakukan hubungan seksual pada remaja laki-laki lebih besar dibandingkan dengan dorongan seksual remaja perempuan. ${ }^{14}$

\section{Hubungan Sikap dengan Perilaku Seksual Pranikah Remaja}

Berdasarkan hasil Penelitian diketahui bahwa responden yang bersikap negatif sebanyak 10 responden $(3.6 \%)$ dengan perilaku seksual pranikah beresiko sebanyak 7 (70.0\%), Sedangkan responden yang bersikap positif sebanyak 266 responden (96.4\%) dengan perilaku seksual pranikah beresiko sebanyak 104 (39.1\%).

Hasil uji statistik menunjukkan $p$-value $=0.095>$ 0.005, maka Dapat disimpulkan bahwa tidak ada hubungan yang signifikan antara Sikap dengan Perilaku Seksual Pranikah Remaja di SMA N 1 Pemali, Bangka Tahun 2016.

Masih banyaknya remaja yang berperilaku seksual beresiko padahal mereka bersikap positif terhadap perilaku seksual dikarenakan adanya penyebab dari faktor lain seperti pengaruh dari paparan media pornografi yang menyebabkan remaja ingin merasakan apa yang dilihatnya karena apabila seseorang terpapar media pornografi akan meningkatkan nafsu seksual..

Penelitian ini sejalan dengan penelitian di SMA Negeri "X" Jakarta yang membuktikan bahwa tidak ada hubungan yang signifikan antara sikap dengan perilaku seksual pranikah pada siswa/siswi. ${ }^{4}$

\section{Hubungan Pola Asuh Orang Tua dengan Perilaku Seksual Pranikah Remaja}

Berdasarkan penelitian diketahui Pola asuh orang tua yang tidak demoktaris sebanyak 66 responden $(23.9 \%)$ dengan perilaku seksual pranikah remaja yang beresiko sebanyak 48 responden $(72.7 \%)$, sedangkan Pola asuh orang tua yang demokratis sebanyak 210 responden $(76.1 \%)$ dengan perilaku seksual pranikah remaja yang beresiko sebanyak 63 responden $(30.0 \%)$.

Hasil uji statistik menunjukkan $p$-value $=0.005$ $<0.05$, maka dapat disimpulkan bahwa terdapat hubungan yang signifikan antara Pola Asuh Orang Tua dengan Perilaku Seksual Pranikah Remaja di SMA N 1 Pemali, Bangka Tahun 2016 dengan dinilai $\mathrm{OR}=6.222$ (dibulat menjadi 6) artinya remaja dengan pola asuh orang tua yang tidak demokratis memiliki peluang 6 kali lebih besar untuk berperilaku seksual yang beresiko dibandingkan dengan remaja dengan pola asuh orang tua demokratis.

Remaja dengan pola asuh orang tua demokratis dengan perilaku seksual pranikah remaja yang beresiko dapat disebabkan karena pengaruh negatif dari teman sebaya sehingga walaupun pola asuh orang tua demokratis tidak menutup kemungkinan remaja untuk tidak melakukan perilaku seksual beresiko.Dibuktikan dari hasil analisis bivariat antara pola asuh orang tua dengan pengaruh teman sebaya didapatkan presentase proporsi bahwa remaja dengan pola asuh orang tua yang demokratis dengan pengaruh negatif dari teman sebaya 
sebanyak 76 responden (36.2\%).Interaksi yang dilakukan bersama teman sebaya berdampak pada perubahan perilaku, gagasan bahkan corak kehidupan kepribadian individu. bahwa segala sesuatu yang bersangkutan dengan tingkah laku, minat, sikap serta pikiran remaja banyak dipengaruhi oleh teman-teman dari kelompok tersebut. informasi yang remaja dapatkan tentang seksual kebanyakan dari teman sebaya mereka, dimana teman sebaya dapat mem-beritahukan tentang hal mengenai seksual yang didapatkannya dari pengalamannya ataupun dari media internet yang kemudian diberitahukan kepada temantemannya serta bujukan dan ajakan dari teman sebaya untuk melakukan perilaku seksual. Sehingga informasi tersebut dapat mempengaruhi perilaku seksual mereka.

Penelitian ini sejalan dengan penelitian di SMA 'MA'ARIF Kecamatan Jabung Lampung Timur tahun 2013yang membuktikan bahwa ada hubungan yang signifikan antara pola asuh orang tua dengan perilaku seksual remaja. ${ }^{5}$

Pola asuh orang tua mendominasi dalam segala hal yang menyangkut remaja dalam tindakan seharihari.sehingga apabila pola asuh dalam keluarga baik maka perilaku anak saat tidak berada dirumah juga akan baik

\section{Hubungan Pendidikan Orang Tua dengan Perilaku Seksual Pranikah Remaja}

Berdasarkan penelitian diketahui pendidikan ayah yang rendah sebanyak 199 responden (43.1\%) dengan perilaku seksual remaja yang beresiko sebanyak 59 responden (49.6\%), Sedangkan pendidikan ayah yang tinggi sebanyak 157 responden $(157 \%)$ dengan perilaku seksual remaja yang beresiko sebanyak 52 responden $(33.1 \%)$ Hasil uji statistik menunjukkan $p$-value $=0.008<0.05$, maka dapat disimpulkan bahwa terdapat hubungan yang signifikan antara Pendidikan ayah dengan Perilaku Seksual Pranikah Remaja di SMA N 1 Pemali, Bangka Tahun 2016 dengan dinilai OR = 1.986 (dibulat menjadi 2) artinya ayah dengan pendidikan rendah memiliki peluang 2 kali lebih besar bagi remaja untuk berperilaku seksual yang beresiko dibandingkan ayah yang berpendidikan tinggi.

Sedangkan hasil penelitian pada pendidikan ibu, pendidikan Ibu yang rendah sebanyak 122 responden (44.2\%) dengan perilaku seksual pranikah remaja beresiko sebanyak 58 responden ( $47.5 \%$ ), Sedangkan pendidikan ibu yang tinggi sebanyak 154 responden $(55.8 \%)$ dengan perilaku seksual remaja yang beresiko sebanyak 53 responden (19.2\%).Hasil uji statistik menunjukkan $p$-value $=0.037<0.05$, maka dapat disimpulkan bahwa terdapat hubungan yang signifikan antara Pendidikan ibu dengan Perilaku Seksual Pranikah Remaja di SMA N 1 Pemali, Bangka Tahun 2016 dengan dinilai $\mathrm{OR}=1.727$ (dibulat menjadi 2 ) artinya ibu dengan pendidikan rendah memiliki peluang 2 kali lebih besar bagi remaja untuk berperilaku seksual yang beresiko dibandingkan dengan ibu yang berpendidikan tinggi.

Dari hasil penelitian didapatkan hasil bahwa pendidikan ayah dan pendidikan ibu memiliki $p$ value $<0.05$ sehingga dapat disimpulkan adanya hubungan yang signifikan antara Pendidikan Orang Tua dengan perilaku Perilaku Seksual Pranikah Remaja di SMA N 1 Pemali, Bangka Tahun 2016.

Penelitian ini sejalan dengan penelitian di SMA Yadika VI Pondok Aren Tanggerang Selatan Tahun 2015 yang membuktikan bahwa ada hubungan yang signifikan antara Pendidikan Orang Tua dengan Perilaku Seksual Remaja. ${ }^{12}$

Orang tua yang memiliki pendidikan yang lebih tinggi cenderung memiliki sumber daya yang lebih besar, baik pendapatan, waktu, tenaga dan jaringan kontak yang memungkinkan mereka terlibat jauh dalam pendidikan anak.Hasil penelitian ini mendukung teori dari Susetya (2008) yang menyatakan bahwa pendidikan otang tua memiliki peran dalam menentukan keputusan untuk anaknya, karena dikeluarga anak pertama kali mendapatkan pendidikan.Bilamana orang tua mampu memberikan pemahaman kepada anaknya mengenai perilaku seksual maka anak-anak cenderung dapat mengontrol perilaku seksual sesuai dengan pemahaman yang diberikan oleh orang tua. ${ }^{1}$

\section{Hubungan Ketaatan Beribadah dengan Perilaku Seksual Pranikah}

Berdasarkan penelitian diketahui responden yang tidak taat beribadah sebanyak 81 responden (29.3\%) dengan perilaku seksual beresiko sebanyak 48 responden $(59.3 \%)$ sedangkan responden yang taat beribadah sebanyak 195 responden (70.7\%) dengan perilaku seksual pranikah beresiko terdapat 63 responden ( $32.3 \%$ )

Hasil uji statistik menunjukkan $p$-value $=0.005<$ 0.05, maka dapat disimpulkan bahwa terdapat hubungan yang signifikan antara ketaatan beribadah dengan Perilaku Seksual Pranikah Remaja di SMA N 1 Pemali, Bangka Tahun 2016 dengan dinilai OR $=3.048$ artinya remaja yang tidak taat beribadah memiliki peluang 3 kali lebih besar untuk berperilaku seksual yang beresiko dibandingkan dengan remaja yang taat beribadah. 
Remaja yang taat beragama dengan perilaku seksual beresiko dapat disebabkan karena adanya paparan dari media pornografi, hal ini dibuktikan bahwa remaja yang taat beribadah yang terpapar media pornografi sebanyak 80 responden $(52.6 \%)$, sehingga informasi media pornografi tersebut dapatmeningkatkan nafsu seksual remaja dan membuat remaja ingin mencoba hal tersebut.

Penelitian ini sejalan dengan penelitian di SMA di Tasikmalaya yang membuktikan bahwa ada hubungan Ketaatan Beribadah Dengan Perilaku Seksual Siswa. ${ }^{2}$

Apabila seseorang memiliki keyakinan terhadap suatu ajaran agama melakukan praktek ibadah sesuai keyakinan tersebut, dan mengamalkan ajaran agama dengan baik dan benar, maka seharusnya tindakantindakan/perilaku-perilaku yang dilarang dalam agama tersebut akan dihindari oleh remaja.

\section{Hubungan Tempat Tinggal dengan Perilaku Seksual Pranikah Remaja}

Berdasarkan penelitian diketahui yang tidak tinggal bersama orang tua (kost/kontrak) sebanyak 14 responden $(5.1 \%)$ dengan perilaku seksual beresiko sebanyak 8 responden $(57.1 \%)$, Sedangkan responden yang tinggal bersama orang tua/keluarga sebanyak 262 responden (94.9\%) dengan perilaku seksual pranikah beresiko sebanyak 103 responden ( $39.3 \%$ ). Hasil uji statistik menunjukkan p-value = $0.296>0.05$, maka Dapat disimpulkan bahwa tidak ada hubungan yang signifikan antara Tempat Tinggal dengan Perilaku Seksual Pranikah Remaja di SMA N 1 Pemali, Bangka Tahun 2016.

Penelitian ini tidak sejalan dengan penelitian di SMK RISE Kabupaten Cirebon Tahun 2015yang membuktikan bahwa ada hubungan antara Tempat Tinggal dengan Perilaku Seksual Beresiko Pada Remaja. ${ }^{9}$

Walaupun tinggal bersama orang tua masih banyak sekali remaja yang melakukan perilaku seksual beresiko hal ini dapat disebabkan karena pengaruh negatif dari teman sebaya, dibuktikan dari hasil analisis bivariat antara tempat tinggal dengan pengaruh teman sebaya didapatkan hasil presentase proporsi bahwa remaja yang bertempat tinggal bersama orang tua dan mendapatkan pengaruh negatif dari teman sebaya sebanyak 118 responden (45.0\%). Interaksi yang dilakukan bersama teman sebaya berdampak pada perubahan perilaku, gagasan bahkan corak kehidupan kepribadian individu. bahwa segala sesuatu yang bersangkutan dengan tingkah laku, minat, sikap serta pikiran remaja banyak dipengaruhi oleh teman-teman dari kelompok tersebut. informasi yang remaja dapatkan tentang seksual kebanyakan dari teman sebaya mereka, dimana teman sebaya dapat memberitahukan tentang hal mengenai seksual yang didapatkannya dari pengalamannya ataupun dari media internet yang kemudian diberitahukan kepada teman-temannya serta bujukan dan ajakan dari teman sebaya untuk melakukan perilaku seksual. Sehingga informasi tersebut dapat mempengaruhi perilaku seksual mereka.

Kemudian bisa disebabkan karena masih banyaknya tempat-tempat yang dapat digunakan remaja untuk melakukan perilaku seksual beresiko seperti dalam penelitian ini remaja melakukan perilaku seksual pranikah seperti di pantai (38.5\%), Rumah (36.3\%), hutan/perkebunan (10.4\%), kost/kontrakan (6\%), rumah kosong $(4.4 \%)$ di hotel (3\%) dan tempat sepi (1.4\%).

\section{Hubungan Paparan Media Pornografi dengan Perilaku Seksual Pranikah Remaja}

Berdasarkan penelitian diketahui responden yang terpapar media pornografi sebanyak 156 responden $(56.5 \%)$ dengan perilaku seksual pranikah beresiko sebanyak 96 responden ( $61.5 \%$ ), Sedangkan yang tidak terpapar media pornografi sebanyak 120 responden $(43.5 \%)$ dengan perilaku seksual beresiko sebanyak 15 responden (12.5\%).Hasil uji statistik menunjukkan $p$-value $=0.005>0.05$, maka Dapat disimpulkan bahwa terdapat hubungan yang signifikan antara paparan media Pornografi dengan Perilaku Seksual Pranikah Remaja di SMA N 1 Pemali, Bangka Tahun 2016 dengan dinilai OR $=11.200$ artinya remaja yang terpapar Media Pornografi memiliki peluang 11 kali lebih besar untuk berperilaku seksual yang beresiko dibandingkan dengan remaja yang tidak terpapar media pornografi.

Penelitian ini sejalan dengan penelitian yang di SMA Yadika VI Pondok Aren Tanggerang Selatan Tahun 2015yang membuktikan bahwa ada hubungan antara Paparan Media Pornografi dengan Perilaku Seksual Remaja. ${ }^{12}$

Berdasarkan penelitian yang telah dilakukan di SMA N 1 Pemali, Bangka Tahun 2016 didapatkan hasil bahwa remaja mendapatkan informasi mengenai seksual dari Majalah Dewasa (14.2\%), Komik (15.3\%), Internet (39.6\%), VCD/DVD (11.6\%), HP/Laptop/Konputer/Notebook (19.6\%).

Aktivitas dan perilaku seksual remaja banyak dipengaruhi oleh kemajuan teknologi, seperti media cetak dan elektronik.Remaja mudah memperoleh hal-hal yang berbau pornografi dari majalah, televisi, dan internet apalagi diperparah dengan berkembangnya teknologi internet yang menembus 
batas negara dan waktu yang memungkinkan remaja mengakses hal-hal yang bisa meningkatkan nafsu seks.Terbukti dari hasil penelitian ini yang membuktikan bahwa remaja paling banyak mendapatkan atau mencari informasi mengenai seksual melalui intenet sebanyak $39.6 \% .^{14}$

\section{Hubungan Pendapatan Keluarga dengan Perilaku Seksual Pranikah Remaja}

Berdasarkan penelitian diketahui responden dengan pendapatan keluarga < UMK sebanyak 140 responden $(50.7 \%)$ dengan perilaku seksual pranikah beresiko sebanyak 61 responden $(43.6 \%)$ Sedangkan responden dengan pendapatan keluarga > UMK sebanyak $136(49.3 \%)$ dengan perilaku seksual beresiko sebanyak 50 responden (36.8\%).Hasil uji statistik menunjukkan $p$-value $=$ $0.303>$ p-value tabel (0.05), maka dapat disimpulkan bahwa tidak ada hubungan yang signifikan antara Pendapatan Keluarga dengan Perilaku Seksual Pranikah Remaja di SMA N 1 Pemali, Bangka Tahun 2016.

Penelitian ini sejalan denganpenelitiandi SMK RISE Kabupaten Cirebon Tahun 2015 yang membuktikan bahwa tidak ada hubungan Ekonomi Orang Tua dengan Perilaku Seksual Beresiko Pada Remaja. $^{9}$

Tidak ada hubungannya pendapatan keluarga dengan perilaku seksual remaja karena dalam kebutuhan keluarga remaja tidak bertanggung jawab dalam pemenuhan kebutuhan sehari-hari.sehingga remaja tidak memikirkan cara mendapatkan penghasilan dan remaja hanya fokus dengan pendidikan saja, sedangkan untuk uang saku mereka bisa mendapatkannya dari orang.

\section{Hubungan Pacaran dengan Perilaku Seksual Pranikah Remaja}

Berdasarkan penelitian diketahui responden yang sedang dan atau pernah pacaran sebanyak 187 responden dengan perilaku seksual pranikah beresiko sebanyak 108 responden $(57.8 \%)$.Sedangkan yang tidak pernah pacaran sebanyak 89 responden $(32.2 \%)$ dengan perilaku seksual beresiko sebanyak 3 responden (3.4\%). Hasil uji statistik menunjukkan $p$-value $=0.005>0.05$, maka dapat disimpulkan bahwa terdapat hubungan yang signifikan antara Pacaran dengan Perilaku Seksual Pranikah Remaja di SMA N 1 Pemali, Bangka Tahun 2016 dengan dinilai OR = 39.190 (dibulat menjadi 19) artinya remaja yang pacaran memiliki peluang 39 kali lebih besar untuk berperilaku seksual yang beresiko dibandingkan dengan remaja yang tidak pernah pacaran.
Hasil penelitian diatas membuktikan remaja yang tidak pernah pacaran juga berperilaku seksual beresiko sebanyak 3 responden $(3.45 \%)$ hal ini disebabkan karena keterpaparan remaja dengan media pornografi sehingga merangsang remaja untuk melakukan perilaku seksual dengan menjadikan dirinya sendiri sebagai objek seksual seperti melakukan onani/masturbasi. Pernyatan ini didukung dengan hasil analisis bivariat dengan presentase proporsi bahwa remaja yang tidak pernah pacaran yang terpapar media pornografi sebanyak 24 responden $(27.0 \%)$

keterpaparan media pornografi juga dapat menyebabkan seseorang untuk melakukan perilaku seksual walaupun seseorang tersebut tidak memiliki pacar. Berdasarkan penelitian ini remaja melakukan perilaku seksual pranikah dengan pacar $(88.5 \%)$, teman $(7.1 \%)$, tante-tante $(3.5 \%)$ dan pacar teman $(0.8 \%)$. hal ini membuktikan bahwa remaja tidak hanya melakukan dengan pacar saja tetapi mereka juga dapat melakukan perilaku seksual dengan teman, tante-tante dan pacar teman.

Hasil penelitian ini sejalan dengan penelitian di SMK RSIE Kabupaten Cirebon Tahun 2015 yang membuktikan bahwa ada hubungan antara Mempunyai Pacar Dengan Perilaku Seksual Beresiko Pada Remaja. ${ }^{9}$

Berdasarkan data diatas membuktikan bahwa remaja paling banyak melakukan perilaku seksual bersama pacar sebesar 88,5\%. Adanya dorongan seksual dan rasa cinta membuat remaja mulai tertarik dengan lawan jenis dan biasanya akan terjalin dalam bentuk jalinan cinta kasih atau yang biasa disebut dengan pacaran. Munculnya dorongan seksual dan rasa cinta pada remaja yang berpacaran membuat mereka ingin selalu dekat dan mengadakan kontak fisik dengan pacar. Kedekatan fisik inilah yang akan mengarah pada perilaku seksual dalam pacaran. Adanya dorongan seksual dan rasa cinta membuat remaja ingin selalu dekat dan mengadakan kontak fisik dengan pacar. Kedekatan fisik maupun kontak fisik inilah yang akan mengarah pada perilaku seksual beresiko pada remaja. $^{6}$

\section{Hubungan Teman Sebaya dengan Perilaku Seksual Pranikah Remaja}

Berdasarkan hasil penelitian diketahui bahwa responden yang mendapatkan pengaruh negatif dari teman sebaya sebanyak 123 responden (44.6\%) dengan perilaku sekual pranikah beresiko sebanyak 91 responden (74.0\%), sedangkan yang mendapatkan perilaku Positif dari teman sebaya sebanyak 153 responden (55.4\%) dengan perilaku 
seksual pranikah beresiko sebanyak 20 responden (13.1\% ) Hasil uji statistik menunjukkan p-value $=0.005<0.05$, maka Dapat disimpulkan bahwa terdapat hubungan yang signifikan antara Pengaruh Teman Sebaya dengan Perilaku Seksual Pranikah Remaja di SMA N 1 Pemali, Bangka Tahun 2016 dengan dinilai OR = 18.911 (dibulat menjadi 19) artinya remaja yang mendapatkan pengaruh negatif dari teman sebaya memiliki peluang 19 kali lebih besar untuk berperilaku seksual yang beresiko dibandingkan dengan remaja yang mendapatkan pengaruh positif dari teman sebaya.Penelitian ini sejalan dengan penelitian di SMK RSIE Kab. Cerebon, Tahun 2015 yang membuktikan bahwa terdapat hubungan yang siknifikan antara Pengaruh Teman Sebaya dengan Perilaku Seksual Beresiko Pada Remaja. ${ }^{9}$

Lingkungan yang telah dimasuki oleh seorang remaja dapat berpengaruh untuk menekan temannya yang belum melakukan hubungan seks. ${ }^{4}$

Hasil studi bertanjuk Sexsual Behavior Surver 2016 yang dilakukan oleh DKT Indonesia, produsen dua merek kondom terlaris meneliti perilaku seksual remaja usia 15-25 tahun menunjukkan bahwa responden mengaku membahas kegiatan seksualnya paling sering dengan sahabat atau teman dekat sebesar 93\%, disusul berssama pacar $21 \%$, dengan ibu $10 \%$, kakak atau adik 9\%. ketika ditanyakan darimana mereka belajar masalah seksual kebanyakan respinden menjawab paling banyak dari teman sebesar $64 \%$. $^{4}$

\section{Faktor Dominan Berhubungan dengan Perilaku Seksual Pranikah Remaja}

Dari hasil analisis multivariat variabel yang berhubungan paling dominan adalah pacaran dengan nilai $\mathrm{OR}=20.783$ (dibulatkan menjadi 21 ) yang artinya responden yang pacaran memiliki peluang 21 kali lebih besar berperilaku seksual pranikah yang beresiko dibandingkan dengan responden yang tidak pernah pacaran.

Hal ini dikarenakan Pacaran dapatmeningkatkan kesempatan pada remaja untuk melakukan perilaku seksual pranikah.Pada masa pacaran, remaja akan mencapai suatu perasaan aman dengan pasangannya. perasaan yang aman ini dapat menimbulkan suatu keintiman seksual pada diri mereka. sejumlah pengalaman pada masa berpacaran dapat memberikan rangsangan bagi remaja untuk melakukan hubungan seksual pranikah. ${ }^{10}$ Pengalaman tersebut didapatkan remaja melalui aktivitas yang mereka lakukan selama pacaran, seperti: berpegangan/bergandengan tangan, memeluk, membelai, mencium dan
seterusnya.Proses pacaran yang dilakukan remaja dipengaruhi oleh pengaruh atau pandangan seseorang terhadap orang laindan kematangan usia yang tidak dibarengi oleh kematangan psikologisnya yang membuat perilaku seksual pranikah akan sangat mudah terjadi. usia kematangan seksual atau biologis remaja belum diimbangi oleh kematangan psikososial, yaitu memahami resiko dari perilaku seksual dan siap menerimanya, kemampuan mengelola dorongan dan kemampuan dalam mengambil keputusan secara matang. Akibat dari rasa ingin tahu, keinginan bereksplorasi dan memenuhi dorongan seksual mengalahkan pemahaman tentang norma, kontrol diri, pemikiran rasional sehingga timbul perilaku mencoba untuk berperilaku seksual beresiko dan pada akhirnya menimbulkan rasa ketagihan pada remaja untuk melakukannya kembali.

\section{SIMPULAN}

Perilaku Seksual Pranikah Remaja di SMA N 1 Pemali, Bangka Tahun 2016 yang beresiko sebanyak 111 responden $(40,2 \%)$ dan tidak beresiko sebanyak 165 (59.8\%).

Ada hubungan antara Pengetahuan, Jenis Kelamin, Pola Asuh Orang Tua, Pendidikan Orang Tua, Ketaatan Beribadah, Paparan Media Pornografi, Pacaran, Teman Sebaya dengan Perilaku Seksual Pranikah Remaja di SMA N 1 Pemali, Bangka Tahun 2016

Tidak ada hubungan antara Sikap, Tempat Tinggal, Pendapatan dengan Perilaku Seksual Pranikah Remaja di SMA N 1 Pemali, bangka tahun 2016

Faktor yang dominan terhadap perilaku seksual pranikah remaja adalah faktor pacaran dengan nilai Odds Ratio (OR) sebesar 20.783 (dibulatkan menjadi 21) yang artinya responden yang pacaran memiliki peluang 21 kali lebih besar berperilaku seksual pranikah yang beresiko dibandingkan dengan responden yang tidak pernah pacaran

\section{DAFTAR PUSTAKA}

1. Alfiani, D.A. Perilaku Seksual Remaja dan Faktor Determinannya di SMA se-Kota Semarang. Skripsi. Fakultas Ilmu Pendidikan Universitas Negeri Semarang, Semarang. 2013.

2. Bulqini, R, M. Perilaku Seksual Remaja dan Fakto-Faktor yang Mempengaruhinya pada Siswa SMA di Kota Tasikmalaya. Tesis. Universitas Indonesia Depok. 2013. 
3. BKKBN. 2012. Badan kependudukan dan keluarga berencana nasional. http://www.bkkbn.go.id. Diakses 5 Oktober 2016.

4. Fariningsih, E.Faktor Instrinsik Dan Ekstrinsik Yang Berhubungan Dengan Prilaku Seksual Pranikah Remaja Pada Siswa Siswi SMA Negeri"X" Jakarta Yang Berpacaran. Tesis. URINDO. 2015.

5. Hendrayani. Hubungan Lingkungan Sosial Dengan Perilaku Seksual Remaja di SMA 'MA'ARIF Kecamatan Jabung Lampung Timur tahun 2013. Tesis. Urindo. 2013.

6. Munir, M. 2010. Tiap Tahun Remaja Seks Pranikah Meningkat. www.okezone.com. Diakses 5 oktober 2016.

7. Nursalam, \& Efendi, F. Pendidikan dalam Keperawatan. Surabaya : Salemba Medika.2008.

8. Novita, O.T. Hubungan Faktor Personal Dengan Prilaku Seks Pranikah Pada Remaja di SMA Negeri 02 Mukomuko Ipuh Bengkulu tahun 2015. Tesis. URINDO. 2015.

9. Puspasari, H. Determinan Perilaku Seksual Beresiko Pada Remaja SMK RSIE Kabupaten Cirebon tahun 2015. Tesis. URINDO. 2015.

10. Imran, Irawati. Modul Dua Perkembangan Seksualitas Remaja. Perkumpulan Keluarga Berencana Indonesia. 2000.

11. Reni. D. P. Perilaku Beresiko dan Faktor Beresiko Kejadian Seks Pranikah Pada Siswa/Siswi SMA Sederajat di Kota Tanggerang Tahun 2015. Skripsi. UIN Syarif Hidayatullah. 2015.

12. Rima, M. Faktor-Faktor Yang Berhubungan Dengan Perilaku Seksual Remaja di SMA Yadika VI Pondok Aren Tanggerang Selatan Tahun 2015. Tesis. URINDO. 2015.

13. Rony Setiawan dan Siti, N. Pengaruh Pacaran Terhadap Perilaku Seks Pranikah. Journal Soul, Vol.1, No. 2. 2008.

14. Tukiran et al. Keluarga Berencana dan Kesehatan Reproduksi. Yogyakarta: Pusat Studi Kependudukan dan Kebijakan Universitas Gadjah Mada. 2010.

15. Willis.S.S. Remaja dan Masalahnya Mengupas Bentuk Kenakalan Remaja, Narkoba, Free Sex, danPemecahannya. Bandung: Afabeta. 2012. 